\title{
Method and Theory: On the Compilation of a Collection of Texts in Estonian Translation History ${ }^{1}$
}

\author{
KATILIINA GIELEN \\ KLAARIKA KALDJÄRV
}

\begin{abstract}
Translation history is a part of cultural history and a necessary component of any literary history, but documenting it may prove to be a challenge. The present article is an attempt to describe and exemplify an ongoing project of mapping Estonian translation history through metatexts on translational issues based on the writings of translators, editors and other figures close to translation throughout Estonian literary history. The reason for collecting translational thought into one compilation lies in the importance of translation for Estonian culture both retrospectively as well as keeping in mind the future of translation and language policies and practices.

The article is thematically divided into two parts. The first part is concerned with the analysis of already existing methodologies for compiling translation histories. Still, in order to get a comprehensive picture, different angles have to be considered and different methodologies applied on the material that has come down to us. Thus, what follows is the description of the ongoing project and its slightly different, empirics driven methodology.

The second part of the paper gives an insight into one of the seven major topics that have emerged from the work with the texts in Estonian translation history. It is based on the discussions whether practitioners need theory, or more generally, what is translation theory and who needs it? The examples are taken from the articles and interviews with Estonian practicing translators and people close to translation such as literary critics, editors, etc. and cover the second half of the $20^{\text {th }}$ century up to the contemporary times. Our aim was to show practitioners as theorists and thus narrow the gap between theory and practice of translation which has proved to be a general problem also in other cultural settings, end even currently when translation studies has established itself as a discipline. The issue has been discussed by many prominent translation studies scholars and the present article will take the opportunity to introduce their points of view.
\end{abstract}

Keywords: translation history; theory of translation; literary translation; history of literature; translators

1 This article was supported by Institutional Research Funding IUT34-30.

DOI: http://dx.doi.org/10.12697/IL.2016.21.1.4 
GIELEN, KALDJÄRV

Although a relatively new trend considering literary histories, the idea of compiling a national translation history is not new in the world and not new in Estonia. Many a national history of translation has already been published. The closest example comes from Finland where a two volume massive edition of Suomennoskirjallisuuden historia was published in 2007. Attempts have also been made in the form of conferences and projects to lay the foundation to an Estonian translation history. An explicit call can be dated back to 1980 and Peeter Torop's (b. 1950) article "Rahvusliku tõlkeloo teadvustamisest" ('Recognition of the National Translation History') in which Torop stressed its importance but at the same time recognized the current unavailability of a database for a translation history (Torop 1980: 63). The idea, however, has been brewing ever since in Estonia. The aim of the present paper is to deliberate on an ongoing project the objective of which is to compile an Estonian translation history through texts on translation, in other words, using metatexts on translational practices that have been written by translators themselves throughout Estonian translation history as well as people interested in translation or involved in translation. The first part of the present paper is dedicated to the questions of the methodology of compiling a translation history in general and the translation history reader under observation; the second part will take a closer look at the ongoing project of Estonian translation history in texts and present the preliminary structure and part of one of the already analysed and commented prominent topics in the compilation - the attitudes and opinions of practicing translators to translation theory.

As an answer to the question why to write a history of translation, the Estonian translation studies scholars Anne Lange and Daniele Monticelli (Lange, Monticelli 2012) jokingly offer a thought of a Baltic-German visionary Georg Julius Schultz-Bertram who has said in 1839 that by giving Estonians an epic and a history they would belong to the civilized world. According to Anthony Pym (2012: 18-19), one of the reasons to be engaged in translation history is that we want to express, address and provide solutions for our everyday translation related practices, provide a clear vision of our "present position and future potential". As scholars, however, insight into history gives us the knowledge of the plurality of thought and prevents us from adhering to one single theory or concept. It is, as Lieven D'hulst (2001) puts it, an eye opener providing us with the necessary flexibility to regularly adapt our ideas and viewpoints. It establishes a culture of translation. 


\section{Writing a translation history: methodological considerations}

There have also been attempts to create a theoretical basis for translation histories. One of the most influential authors in the field is Anthony Pym who says that the translator needs to be the centre of research in translation history, since only people (not texts, context or linguistic markers) are agents in social causality. He devises three basic principles of a translation history in his Method in Translation History, first published in 1998. According to Pym, a translation history should, firstly (translation archaeology), contain answers to questions such as who translated what, how, where, when and for whom and with what effect. Secondly, be engaged with historical criticism that puts translations in the context of their time. And thirdly explain why translations occur at a certain time in a certain place (in other words, deal with the social causality of translations). He says that archaeology comes down to lists, criticism to analysis and argument and explanation to good storytelling.

Lieven D'hulst (2001) in "Why and how to write translation histories?", presents a schema based on rhetorical parameters that consists of eight questions. Who? What? Where? (Where have the translations been published, where do the translators and translation agents live and work, under which institutions are translations carried out.) By whose assistance? (Patronage, publishing systems censorship issues, ideology.) Why? (Why do translations exist, why do they perform the way they do etc.?) How? (What does the process look like, how do the translation norms change, how do translation theories come to be?) When? Who profits? (What is the function of translations, its influence and impact in a given society?) While Pym prominently brings in the agency and flexibility in history oriented translation research, D'hulst's model is built on factual material and the aim is clearly to delineate a properly documented translation history.

Coming closer, Peeter Torop, a prominent Estonian scholar, has also contributed to the field by offering a preliminary methodology for translation history in 1989 in a scientific journal Akadeemia, called "Tõlkeloo koostamise printsiibid" ('The Principles of Compiling a Translation History'). According to Torop $(1989,1999: 43)$, a translation history should also contain translation criticism and theory of translation. He makes a distinction between four components of a history of translation: the acronic theoretical component, the centre of which is the translator and the analysis of the translation method; the synchronic receptive component, the focus of which is the analysis of the translator and translation in the receiving culture (the status, function and ways of understanding translation in the target culture); the evolutionary component i.e. the analysis of the technical and psychological peculiarities 
GIELEN, KALDJÄRV

of the translation process; and fourth, a component of cultural history, observing the development and change of translation practices throughout larger historical periods (1999: 45-46). Such treatment prominently extends the field to look into a larger cultural-historical landscape through metatextual information in addition to the Who? What? Where? Why?

However, no matter what methodology is used, describing more or less distant events involves a certain amount of subjectivity and partiality. Any history reflects the opinions of its writers as well as the time and place of its writing. Therefore, striving to cover every possible aspect and devise a method that would provide a wholescale map of the landscape under description is a goal that is difficult to achieve. Moreover, the somewhat artificially devised methods remain separated from the actual empirical data, from the actual work with historical texts. Despite of the method, it is therefore important to recognize that any history as such must be quite subjective, have different lacunae and mirror not the entire picture but the authors' take on the history rather than anything else.

Although the methodologies described above could, with some adaptation, be used as models for more or less any history of translation, there are other options. One of them is to start from another end and let the data lead the way and determine the directions of the research. Having come so far, we intuitively reach the borderlands of grounded theory, a way of conceptualising data known and practiced in social sciences, a method first described by Glasner and Strauss (1967). According to the grounded approach, a researcher develops the attitudes and angles towards his/her material through the data analysis and not through the accommodation and application of a readymade theory which could backfire by fitting to no data at all. In order to formulate the focus of research and develop a research question, the researcher lies heavily on the data. It is the material researched that will reveal the foci and determine the directions of research. Hence, in case of a translation history, the researcher will start out from a relatively blank sheet, collecting the qualitative data - writings by the translators, editors, literary critics, opinionated readers, etc. - anybody who has had something to say about issues concerning national translational practices throughout centuries. In other words, collect and systematise historical criticism, metatextual material mentioned by both Pym and Torop. Consequently, at some point the raw material itself will start dictating the what and the how proposed by the researchers mentioned above. The textbook on history starts writing itself. As the researchers involved review the data collected, repeated ideas, concepts or elements become apparent, and can be differentiated and grouped using codes or code names, such as 'translators on theory' or 'the translator must', which 
have been extracted from the data and exemplify prominent issues stemming from the clusters of historical texts with similar themes. Such a history will not be a chronological account, but an idea or concept centred compilation covering the emerging patterns of translational thought from as early as the first available texts, depending on what has come down to us.

\section{Estonian translation history in process}

Such a selection of data with different focal cores in mind can give a more general picture of the topics that emerge as the most prominent in Estonian translation history. These are the topics that have spurred the most heated discussions and that surface every now and then in the course of the history of translation. In such way we can provide an overview of the translational landscape and its idiosyncrasies and diversity in comparison with other histories of translation. The topics that surface are significant since they elucidate the main characteristics of importing foreign texts and thought into Estonian culture. Keeping in mind the evident connection between translational practices and the development of a literary language and culture, we may be able to map and define key issues concerning Estonian society in general. What is more, the commented compilation will provide a comparative database for other similar researches in any cultural environment.

The objective of the compilers, however, is not a complete and authorised translation history that would leave the impression of covering everything (who translated what and when), but rather a compendium of noteworthy metatexts on translation practices in Estonia from as early as the second half of the $17^{\text {th }}$ century to the most contemporary texts written in the $21^{\text {st }}$ century. Yet, due to the idiosyncrasies of both Estonian history and the development of the Estonian literary language, the main core of the discussions will concern the $20^{\text {th }}$ century. The texts have been chosen for their historical importance or uniqueness at a certain point in time or for the importance of their authors in the Estonian cultural landscape. The reader might have a slightly different target readership from a proper translation history, but if documenting the history in one way or another is the goal, it might serve the interests of different parties from scholars to students of translation. In the case of such a national history reader, the problem of contextualisation still remains. In addition to that, there is a certain inevitable randomness of the texts that as well as the impartiality needs to be addressed. One has to recognize that such a compilation can only be partial and full of unmapped areas and periods, but by openly recognizing the partiality and describing the processes as well as 
GIELEN, KALDJÄRV

the standpoints of the compilers, we can claim certain validity and show our endeavour towards objectiveness.

Such a partial but self-positioned and grounded approach has enabled us to witness practicing translators and other figures standing close to translation practices throughout the Estonian history of translation sharing their opinions about several topics. From the available material seven prominent topic clusters have been elicited, exemplified by the most telling texts or extracts of texts. These seven topic-wise arranged text clusters are supplied with an introduction by the researchers that analyses and comments on the samples putting them into a temporal contextual frame. The reader will contain commented sample texts on the following broader themes. 1 . What to translate, or deliberations on what we need in our culture from the standpoint of developing the literary canon. 2. What the translator must (not) do, or in other words, samples from a long-standing tradition of expressing descriptions and prescriptions of how translators must translate. 3. Translational debates and arguments, or different clashes of opinions on the subject of translation at different points in time. 4. Translation and the development of the Estonian language, a topic that has accumulated quite an array of opinions especially during the first half of the $20^{\text {th }}$ century - the time of active and conscious development of the Estonian language. 5. The translator's position or the in/visibility of the translator, or viewpoints on the position as well as the mission of the translator in Estonia. 6. Translators and theory of translation, the topic that is briefly presented below, aims to cover the attitudes of the practicing translators to translation theory. 7. Translation of specific genres (poetry, drama), or discussions and theoretical thought on the translation of poetry and its adjacent field, drama, genres that have to take into consideration also rhythm, rhyme and metre as well as performativity of the translation. All in all, with the chosen historical texts we aim at painting a picture of what has been central to Estonian translational culture at different points in time and how translational thought has travelled and norms of translation developed and changed over time.

As mentioned above, one of the topics that many prominent figures in Estonian translation have taken up is the relationship between translation theory and practice. A historical view on translation practices helps to see the patterns in translational behaviour, but at the same time, it also shows how diverse these practices can be even within one small culture and even at one certain point in time. Talking about translation, we inevitably theorise the practice and thus, finding out more about how translators attribute meaning to their activity has a practical value and direct connection to the position translation has had, and the ways translation has been regarded 
in this particular culture. This also has an effect on the choice of translated literature - canon of translation - and the views on how we perceive what can be considered a 'good' and what a 'bad' translation. On the other hand, translators, when talking about their activity, reveal attitudes that set the scene for the prospective practices; the system, thus, tends to reproduce itself. What is more, the socio-cultural system influencing translators and the translators, in their turn, reproduces the expectancies of the system towards the activities of the translators.

In the following we will present some comments on the attitudes Estonian translators have had regarding translation theories. Our aim here is not to split practitioners and theorists but to analyse the relationship between practical translation work and theorising over translation with a proposition to regard practitioners as theorists. The following will, in very brief terms, exemplify the analysis of one of the seven general clusters of prominent topics that have emerged through collecting and systematising Estonian translational thought: translators and their relationship to the theories of translation.

Theory of translation: a relationship of misunderstanding and rejection?

In the preface of his book The Manipulation of Literature (1985), Theo Hermans describes possible explanations to the fact that the study of translations of literature has long been a neglected topic. Those reasons may also be used, at least partially, to cast light on the distrust of practicing translators and some representatives of the humanities towards translation theory. Since Romanticism literature has been understood as an original and creative field, which circumstance has led to considering translation a second-rate activity that never achieves the perfection of the original. A second-rate activity can only have instructions, not an independent theory. This point of view makes the translator think about their work as craftsmanship carried out in seclusion. Secondly, Hermans mentions linguists whose first attempts to explain translational activity may have seemed somewhat too mechanical and inadequate for literary translations. Thirdly, research into psychology has not been able, in spite of all efforts, to explain what is going on in the translator's "black box" during the translation process.

Describing the beginnings of translation theory in Soviet Union, Uno Liivaku (b. 1926) and Henno Meriste (1918-1984), the authors of the first theoretical textbook on translation in Estonian, say: "Some translators of literature who considered their work and translation generally as artistic 
production, denied the need for any kind of translation theory, especially, of course, theory concerning the translation of literary texts." (Liivaku et al. 1975: 32) $)^{2}$ This point of view has to be placed into its historical context when translation theory was only just emerging and its starting points were mostly linguistic ones. However, such a postulation is not strange to the translators nowadays either, and helps to explain to a certain extent the reluctance of many concerning translation theory. Even now, when translation studies have some history to them, there has not been a complete understanding of the role and function of theoretical thought among practicing translators and even literary scholars, as demonstrated by the consistent labelling, whether directly or in passing, of translation studies as deadwood, a burden to practical activities or as something abstract, floating in the clouds. It is much more difficult to find examples of translators who miss theory and find it useful. For example, one exception is Rein Sepp (1921-1995), a translator of ancient Germanic epics into Estonian, who has said: "I am convinced that a need for the creation and development of a more secure theoretical base exists, and furthermore, that is a very serious one." (Torop, Sepp 1981)

In their book Liivaku and Meriste (1975) describe the initial stages of contemporary translation theory and the opposition of translators to it. They reject the suggested possibility of studying translations by using the framework of other, already existing disciplines, especially linguistics and literary theory. They point out the contradictions inside the young discipline, find them to be natural and think that all these different positions can find their place in translation studies independent of the object of study - whether it is translation as a process or translation as a result, and regardless of the discipline - linguistics or some other field. "Occasionally, positions on translation theory have been exposed in translation criticism, the main arena of treating the questions about translating, but a review is always a post-factum wisdom, it does not substitute for translation studies/theory." (Liivaku, Meriste 1975: 33). Translation theory and studies should bring forth the method of a translator, the individuality of the translator's creative personality, increase the translator's visibility, whereas criticism is mostly incapable of achieving this. Yet, in Torop's words:

In most cases the individuality of the translator is not brought forward, it is replaced with a general discourse about the merits of the book and the author or simply with comments about the text. As a result, the translator as a creative personality disappears from literary culture. This explains the need for theory.

2 Quotes translated by Katiliina Gielen and Klaarika Kaldjärv. 
Method and Theory

The incapacity for seeing a translator in the translation means the incapacity for distinguishing the general and neutral from the individual. (Torop, Sepp 1981)

Our research has shown that earlier discussions about translation criticism in Estonia were mostly devoted to formal questions: vocabulary choices, use of foreign words, meter etc. What has been less discussed is the purposefulness and functionality of the choices made by a translator, the interdependence of the whole imagery of the writers and their work on those choices, the arbitrary, conventional or normative character of seemingly unquestionable choices. When the translational image, behaviour and norms change, speaking about translation becomes more important, and the investigation to achieve an understanding of such changes proves to be necessary. With norm-changes it also becomes evident that the previous situation need not have been the one and only right one. For example, we can observe how Jaak Rähesoo (b. 1941), an Estonian translator and theatre critic, stresses the necessity to explicate translation strategies:

More diverse and more complicated language choices remind us more intensely that translational decisions are never self-evident, but always profoundly problematic. [...] As an overall result, we are not talking any more so much about right or wrong translations (with the exception of certain independent cases), but rather about intelligent or unintelligent, exciting or dull mediation strategies. It is time to present these problems to the average reader in the commentaries to the translations. (Rähesoo 2014: 8)

\section{Theory in heavens, translation on earth}

Misunderstandings may have arisen from contacts with a certain kind of theory that mechanically prescribes translational choices which have conveyed an impression that theory is something normatively imposed that narrows down the translator's liberty of choice and creativity. In an interview with Rein Sepp, Peeter Torop argues, "Naturally, translation theory can never be normative, at the present moment, at least, the most important goal is to understand translational activity itself." (Torop, Sepp 1981) However, the intent to avoid being prescriptive at all costs has led, in turn, to a situation where practicing translators cannot see theory as something useful. Andrew Chesterman points out how for several decades mainstream translation 
theorists have held the view that they "should seek to be descriptive, to describe, explain and understand what translators actually do, not stipulate what they ought to do" (Chesterman and Wagner 2002: 2). This is why translation theorists have created and maintained the gap often criticised by practicing translators. Jean F. Boase-Beier says in his article "Who Needs Theory" (1995) that descriptive translation theory has actually a considerable influence on how we see certain things, "but a theory that is descriptive generally aims to explain as well as to describe; for this reason Toury refers to work done within Descriptive Translation Studies as "descriptiveexplanatory". And it is because of this explanatory function of theories, even in the humanities, that they affect the way we approach tasks in the particular area that has been explained. They become part of our cognitive context, of what we know and think about a particular area" (Boase-Beier 1995: 15).

Many of the Estonian practicing translators under observation claim that theory does not help a translator or make the translation any better. The act of translation is carried out by intuition and experience, and a deeper reflection about the essence of their work may mislead translators. Märt Väljataga (b. 1965), a literary critic, translator and editor, strongly doubts the usefulness of translation studies for a practicing translator:

"Translating is a skill that is mostly intuitive, on which rules can hardly be drawn up, which can be developed by means of experience and reading, work and effort, comparison and feedback. Maybe also with the help of translation studies? Perhaps not really. To reflect on his/her work it is mostly enough for a translator to turn to the grammatical categories taught at school, more sophisticated tools - translation semiotics etc. - are actually unnecessary." (Väljataga 2008)

Seconding to Väljataga, the experienced contemporary Estonian literary translators Küllike Tohver (b. 1955) and Kersti Unt (b. 1950), are also of the opinion that the professional translator knows that translating is a reclusive, individual, concrete, practical and immediate activity (Martson, Unt, Tomasberg, Tohver 2014). Besides, speaking about translation is complicated, if not impossible altogether, and all sorts of theories will only make the picture more blurred: "The treating of translation is made more turbid by some extravagant theories which claim that it is altogether impossible to re-express something in other words, not to mention words of another language." (Väljataga 2008)

The most meritorious translators and writers have no need to use extenuating ambiguous words to justify their opinions. For instance, Jaan Kross (1920-2007), an outstanding writer of historical novels, a few of which are translated into various foreign languages and a well-known translator 
says: "I do not believe in the existence of any translation theory that is even slightly productive. One must translate well, one must translate right, one must translate adequately, one must translate in such a manner that when reading the translation you have an impression of reading the original." (Kross 2003: 210) Talking about the intimidating character of theories and their unstoppable invasion, Mati Sirkel (b. 1949), one of the most eminent Estonian literary translators, a long-time Chairman of Estonian Writers' Society, uses exorcising Latin words: "Concerning the compendiums of translation theory already constituting whole libraries, I take a completely subjective freedom and responsibility to say: horribilis!" (Sirkel 2014: 9) A translator has every right to feel condescending towards theory. "For the same reason the discourse practiced under the name of translation studies makes a professional translator smile ironically - when compared to the everyday problems of translational work it seems so out of touch and far from reality, especially when the theoretical tractate avoids giving examples." (Väljataga 2008)

Another opinion often expressed by Estonian literary translators is that theorists play the glass bead game but practitioners are doing the dirty work, "in translation theory different interpretations are spread, every researcher builds his/her own house of cards. And why not, I consider it an exciting game. But speaking about the fact that theory proves to be useless when approaching a concrete text, then it is also only natural." (Martson in: Martson, Unt, Tomasberg, Tohver 2014: 49) "On a high generalization level, the way philosophers and translation theorists approach translating and interpretation, the relationship between those approaches and a concrete translation case remain remote. Generalizations cleansed from the object may live on their own in the sky of abstractions, but practice often follows its own path down to the earth." (Tomasberg in: Martson, Unt, Tomasberg, Tohver 2014: 50)

According to the practitioners, it is possible to speak about literature by means of literary theory, yet in the case of translation studies a gap between the practical activity and an abstract theory becomes an obstacle, "If in interpreting literature it is good to proceed from theory and find more and more fresh and interesting interpretations in its light, it is just this gap between the translator's activity and the talk about translating that restricts speaking about translating." (Unt in: Martson, Unt, Tomasberg, Tohver 2014: 52) Nevertheless, in 1962 Otto Samma (1912-1978, an Estonian translator and editor) compared translation theory with literary theory, favouring the former,

Now and then it has been argued that we do not need a translation theory at all. As the translation of literature is art, no theory can teach anybody to translate well. The good or bad outcome is said to depend on the talent of the 
GIELEN, KALDJÄRV

\begin{abstract}
translator - so what do we need theory for? We can oppose this point of view with an argument that literary theory (whose usefulness is hardly questioned) has also not been able to teach anybody how to be a good writer if the person himself does not have talent or vocation. However, literary theory can direct/ guide the development/history of literature, explain what is good and what is bad; and surely the writers have got something useful out of literary studies and criticism. (Samma 1962: 390)
\end{abstract}

With this point of view Samma diversifies the general landscape of the opinions about translation theory and makes an attempt to bridge the gap between theory and practice.

\title{
Every translator is a theorist
}

Douglas Robinson affirms that in the Western world translation theory has already been recognized from its beginnings as normative. Starting with Cicero and St. Jerome, translators and theorists have been following in their footsteps, assuming not only that a translation can be free or literal, but also that theory has to take sides and choose one of them in order to tell the translators how to translate. Those who speak about translations and translating but do not give instructions for translating are therefore not considered translation theorist at all (for example Herodotus). During the last decades, the belief that translation theory should invent normative rules for translators has become an object of severe criticism and many theorists have tried to speak about translating without normativity; nevertheless, the idea about the relationship between theory and practice deeply rooted during the past centuries refuses to disappear. Even those translators, who do not show respect towards theory, pointing to its patronizing nature (as if translators did not know how to translate and should wait for the help of theorists) and negativity (pointing out mainly translators' mistakes), are waiting for help and advice from normative theorists (Robinson 2004: 161-163).

All this is reflected in the contradictions inside theory between "pure" and applied translation studies. The descriptive branch of translation studies tried to liberate itself from the prescriptive reputation and only to describe, explain and intend to understand what translators are doing and not to lecture to them (what strategies are used by translators in certain linguistic and socio-cultural conditions, what norms they follow, what values are behind these norms, how the readers, cultures and intercultural relationships are influenced by the translators' choices) (Chesterman 1997: 48, 52). Chesterman describes the relationship between a translator and a theorist through misunderstandings 
that rule over them: from the point of view of a practicing translator, theorists seem to be somewhere up there and in the possession of knowledge that they hand out to translators located underneath and who are waiting for instructions on how to translate better. The majority of contemporary translation researchers consider this point of view strange, because they try to describe, explain and understand what translators are actually doing and from this descriptive point of view, it is the translators who are "up there" and theorists "underneath", attempting to understand how translators are coping (Chesterman, Wagner 2002: 2). Nevertheless, translators get confused or upset by the idea that their activity is being analysed or dissected; they like their work to be spoken about as something complicated and indescribable, even mysterious; they are less liable to allow observation of their work and pointing at its shortcomings. Most frequently it is argued that every problem, text or translation is different, which means that generalizations and hence repeatedly usable strategies are out of the question. It is also said that the terminology used in translation theories is so complicated, esoteric and far from real-life translations that translators are unable to use it in their work (Mailhac 2007).

Acknowledging that there is no definite proof about theory actually helping the translator to translate better, Pym enumerates a list of factors that translators may benefit from knowing theory. According to him, all translators theorise, not only those who express their theories by means of technical terms (Pym 2012a). Translators without translational education are perhaps faster and more effective, because they know less about sophisticated theories, therefore they have fewer doubts and they waste less time pondering over obvious issues. On the other hand, from the practical point of view, it may be useful to possess some knowledge about different theories when it is necessary to deal with problems which have no determined solutions. Theories may help to ask creative questions and every now and then not to give obvious answers. Certain theories may help translators to improve their professional self-image. As theory shows us that things can be seen in various ways, knowledge of theory gives us an ability to question conventional approaches.

In the interview by Andrew Chesterman with Emma Wagner called "Can Theory Help Translators: A Dialogue Between the Ivory Tower and the Wordface”, Emma Wagner points out: “There can be few professions with such a yawning gap between theory and practice" (Chesterman, Wagner 2002:1). Torop, in his interview with translator Rein Sepp, suggests that if the translators would take a step towards theory, theory would meet them halfway: 


\begin{abstract}
Being aware of theories is in great deal a question of the translator's selfawareness. Every good translator is a practical theoretician and our current sentiments prove it again. I only wish that you and your good colleagues would find more time to put your translation wisdom down in writing, to describe the everyday practices. This would help to guarantee the next generation of translators as well as develop the readers and increase understanding of the work of the translator. Such practical theory of the translators would help create a national translation theory that in its turn would help the translator in his/her practical work. (Torop, Sepp 1981)
\end{abstract}

The above was a draft of one of the topics in the upcoming Estonian translation history reader/textbook that will hopefully provide a condensed overview of the multilayered nature of the relationships that exist in the (Estonian) translational world including the tensions and contradictions arising between the participants in the process. The reader will give an overview of the aspects of translation history that have to do with the importance of discussing and addressing translation in a culture. All this has an impact on the field of translation in a more general sense - if many translators do not consider discussions about translation to be reasonable, necessary or even possible and regard translation to be an intimate sphere of activities which requires intuitive action, then such a point of view certainly influences both their translational activities as well as the opinions of the recipients of translations - the readership and its taste in general. Since the products of translation are public and available, they influence larger cultural processes and there is all the more reason to compile a history based on metatexts of translation.

The reason for collecting Estonian translational thought into one compilation lies in the importance of translation for Estonian culture both retrospectively, from the historical point of view, as well as keeping in mind the future of translation and language policies and practices. Translation history is an integral part of cultural history and a valuable component of any literary history. The role of translators and translations is of fundamental importance for a translation history and the most accurate view of the field can be acquired by documenting what has been translated and how. Still, in order to get a comprehensive picture of a discipline, different angles have to be considered and different methodologies applied on the material that has come down to us. The opinions of practicing translators can be the means to unify the field into a homogeneous discipline. The project described above will make theorists out of practitioners with the aim of breaching the gap between theory and practice and presenting translational issues through the eyes of 
Method and Theory

the practitioners, that is, through their theories of translation. Thus, without even knowing or recognizing it, many practitioners turn out to be translation theorists.

\author{
Katiliina Gielen \\ katiliina.gielen@ut.ee \\ Tartu Ülikool \\ Lossi 3-303 \\ 51003 Tartu \\ EESTI / ESTONIA \\ Klaarika Kaldjärv \\ klaarika.kaldjarv@ut.ee \\ Tartu Ülikool \\ Lossi 3-420 \\ 51003 Tartu \\ EESTI / ESTONIA
}

\title{
Bibliography
}

Boase-Beier, J. 2010. 'Who Needs Theory?’. - A. Fawcett, K. L. Guadarrama García, R. Hyde Parker, eds. Translation: Theory and Practice in Dialogue. London: Continuum, 25-38, http://www.academia.edu/382280/Who_Needs_Theory (19.05.2016).

Chesterman, A., Wagner, E. 2004. Can Theory Help Translators: A Dialogue Between the Ivory Tower and the Wordface. Manchester, UK: St Jerome.

Chesterman, A. 1997. The Memes of Translation. Amsterdam: John Benjamins B.V.

D'hulst, L. 2001. Why and how to write translation histories? - Crop, 6, 21-32.

Glasner, B., Strauss, A. 1967. The Discovery of Grounded Theory. Hawthorne, NY: Aldine Publishing Company.

Hermans, T. 1985. The Manipulation of Literature. Studies in Literary Translation. 1, 1. London and Sydney: Croom Helm.

Kross, J. 2003. Omaeluloolisus ja alltekst. Tallinn: Eesti Keele Sihtasutus.

Lange, A., Monticelli, D. 2012. Kuidas kirjutatakse tõlkelugu? - Methis. Studia humaniora Estonica, 9/10, 5-23.

Liivaku, U., Meriste, H. 1975. Kuidas seda tõlkida : järeltormatusest eestinduseni. Tallinn: Valgus.

Mailhac, J.-P. 2007. Formulating Strategies for the Translator. - Translation Journal, 11/2, http://translationjournal.net/journal/40strategies.htm (19.05.2016).

Martson, I., Unt, K., Tomasberg, L., Tohver, K. 2013. Kuus küsimust Eesti Kultuurkapitali 2013. aasta tõlkekirjanduse auhinna nominentidele. - J. Kaus, T. Tamm, eds. 
GIELEN, KALDJÄRV

Tõlkija hääl II. Eesti Kirjanike Liidu tõlkijate sektsiooni aastaraamat. Tallinn: Eesti Keele Sihtasutus, 49-67.

Pym, A. 2012a. Teorías contemporáneas de la traducción. Materiales para un curso universitario. Tarragona: Intercultural Studies Group, http://isg.urv.es/publicity/ isg/publications/2011_teorias/index.htm (19.05.2016).

Pym, A. 2012b [1998]. Method in Translation History. Manchester: St Jerome Publishing.

Robinson, D. 2004. Normative model - M. Baker, K. Malmkjaer, eds., The Routledge Encyclopedia of Translation Studies. London and New York: Routledge, 161-163.

Rähesoo, J. 2014. Tõlkimise probleemsus. - J. Kaus, T. Tamm, eds. Tõlkija hääl I. Eesti Kirjanike Liidu tõlkijate sektsiooni aastaraamat. Tallinn: Eesti Keele Sihtasutus, 6-8.

Samma, O. 1962. Üht-teist tõlkimisest ja tõlkijatest. Keel ja kirjandus, 7, 385-392.

Riikonen, H. K., Kovala, U., Kujamäki, P. , Paloposki, O., eds. 2007. Suomennoskirjallisuuden historia. Helsinki: Suomalaisen Kirjallisuuden Seura.

Sirkel, M. 2014. Arusaamatus ja arusaam. - J. Kaus, T. Tamm, eds. Tõlkija hääl II. Eesti Kirjanike Liidu tõlkijate sektsiooni aastaraamat. Tallinn: Eesti Keele Sihtasutus, 8-9.

Torop, P. 1980. Rahvusliku tõlkeloo teadvustamisest. - Keel ja Kirjandus, 1, 63-64.

Torop, P. 1989. Tõlkeloo koostamise printsiibid. - Akadeemia, 2, 349-384.

Torop, P. 1999. Kultuurimärgid. Tartu: Ilmamaa.

Torop, P., Sepp, R. 1981. Tõlkimise teooriast ja praktikast. - Sirp ja Vasar, 3, 6-7.

Väljataga, M. 2008. Tõlkimise teooriast ja praktikast. - Sirp, 27.11. 